\title{
Effect of Silicon and Saline Irrigation Water on Productivity of Two Wheat Cultivars at South Sinai, Egypt
}

\section{Howaida A. Maamoun}

Unit of Agronomy, Plant Production Department, Desert Research Center, Cairo, Egypt.

\begin{abstract}
7 WO field experiments were conducted at Ras-Sudr Research 1 Station, South Sinai Governorate during two successive seasons, $2011 / 2012$ and 2012/2013, to study the effect of three levels of silicon as $\mathrm{KAlSi}_{3} \mathrm{O}_{8}$ incorporated to the soil at $(100,200$ and $300 \mathrm{~kg} / \mathrm{fed})$ compared by control (without silicon) on two wheat cultivars Sakha 94 (salt-tolerant) and Gimeza 10,( salt-sensitive). Both cultivars were irrigated from two wells different in salinity levels (4236 and 4748 ppm, moderate level) and (7001 and 7360 ppm high level) in the first and second seasons, respectively.

Obtained results showed that increasing irrigation water salinity from (4236 up to $7001 \mathrm{ppm}$ ) in the first season and from (4748 to $7360 \mathrm{ppm}$ ) in second season, decreased the grain yield and its components in Sakha 94 and Gimeza 10. Gimeza 10 was superior to Sakha 94 in all yield criteria in the two growing seasons except protein yield was superior in Sakha 94. The highest level of silicon (300 $\mathrm{kg} \mathrm{KAlSi}{ }_{3} \mathrm{O}_{8} /$ fed) had the superiority effect in decreasing the soil salinity hazard and consequently increased significantly all yield criteria of the two cultivars.
\end{abstract}

The effect of second order interaction indicated that incorporated soil by silicon $(300 \mathrm{~kg} / \mathrm{fed})$ planted with Gimeza 10 which irrigated by (4236 and $4748 \mathrm{ppm}$ ) produced the highest grain yield and yield components in both seasons. However, the highest protein yield has been resulted in Gimeza 10 treated with silicon (300 kg/fed). Grain yield were significantly improved in Gimeza 10, than Sakha 94, with application of silicon $(300 \mathrm{~kg} / \mathrm{fed})$.

Potassium content was significantly increased in grain wheat cultivars due to soil application of silicon under saline soil conditions. Sodium content was higher in grain wheat, cv. Sakha, 94, under saline soil condition; however $\mathrm{Si}$ application significantly reduced $\mathrm{Na}$ content in grain, while it significantly increased in K: Na ratio. High K and low $\mathrm{Na}$ contents in grain wheat cultivars may be one of the possible mechanisms of increasing salinity tolerance by silicon application.

In general, the current research suggested that $\mathrm{Si}$ application not only increased the quantity, but also enhanced the quality of wheat cultivars grown under salt stress conditions. Therefore, silicon at the

Howaida64@hotmail.com 
rate of $300 \mathrm{~kg} / \mathrm{fed}$ and Gimeza 10, which irrigated with moderate level of salinity (4236 ppm) encourage the farmers to use of silicon to give promising grain yield.

Keywords: Saline irrigation water, Silicon, Wheat cultivars, Potassium, Sodium, Yield, Yield components.

The new goals of the Egyptian agricultural policy are to increase wheat production through the expansion of the cultivated wheat area by high production cultivars in the newly reclaimed land to offset the gap between the production and consumption (Abd El-Monem, 2010). The most new reclaimed soils in Egypt are subjected to salinity stress such as Ras-Sudr in South Sinai. The rainfall or the existing fresh water in this region is limited, so, irrigation in this region depends mostly on wells. Also, the soil of Ras-Sudr is saline and highly calcareous (Hendawey, 2009).

Soil salinity is a major problem in agriculture. The major constraints for plant growth and productivity are ion toxicity with excessive uptake of mainly $\mathrm{Cl}^{-}$and $\mathrm{Na}^{+}$as well nutrients imbalance caused by disturbed uptake of essential mineral nutrients (Hellal et al., 2012). Living with salinity is the only way of sustaining agricultural production in the salt affected soil (Al-Rawahy et al., 2011). So that, it is important to find the best management to alleviate salt hazard.

Wheat is adversely affected by salinity stress (Zhu, 2003). Yield losses up to $45 \%$ have been reported due to salinity stress in wheat (Qureshi and BarrettLennard, 1998). To ensure food security and sustainable economy, there is dire need to find ways to improve salinity tolerance of wheat. Various chemical, physical and biological strategies are adapted for economic crop production on such soils (Ashraf and Harris, 2004). Of all these strategies, exogenous application of nutrients has gained a considerable ground as a shotgun approach to ameliorate the adverse effects of salt stress (Grattan and Grieve, 1999). For example, exogenous application of $\mathrm{K}$ ameliorated adverse effects of salt stress in wheat (Akram et al., 2007), Ca in bean (Awada et al., 1995) and $\mathrm{N}$ in Phaseolus vulgaris (Wagenet et al., 1983).

Furthermore, some non-essential mineral nutrients may also counteract adverse effects of salt stress. For example, silicon is a non-essential element for plant growth (Tahir et al., 2006), however, various studies have demonstrated that $\mathrm{Si}$ application significantly increased plant growth under normal (Agurie et al., 1992) and stress conditions including biotic and abiotic stresses as salt stress (Ma, 2004). A number of possible mechanisms are proposed through which Si may increase salinity tolerance in wheat (Ali et al., 2012), e.g., improving water status (Romero et al., 2006), increased photosynthetic activity and ultra structure of leaf organelles (Shu and Liu, 2001), stimulation of antioxidant system (Zhu et al., 2004) and alleviation of specific ion effect (Rafiq et al., 1992) by reducing Na uptake (Gong et al., 2003 and Liang et al., 2003). Si content in soils varies greatly and ranges from 1 to $45 \%$ by dry weight (Sommer et al., 2006). The agricultural

Egypt. J. Soil Sci. 54, No. 4 (2014) 
benefits of silicon amendments on a soil ecosystem are well established. Keeping all beneficial mechanisms of $\mathrm{Si}$ in salinity tolerance of wheat plants, the present study was conducted to evaluate yield and yield components and protein yield of two wheat cultivars; Gimeza 10, (salt-sensitive) and Sakha 94, (salt-tolerant), grown under saline soil conditions with different levels of Si and irrigated by two salinity levels of wells.

\section{Material and Methods}

Two field experiments were conducted at Ras-Sudr Agricultural Experimental Station of Desert Research Center, South Sinai Governorate, Egypt, during 2011/2012 and 2012/2013 seasons to study the effect of three different levels of silicon incorporated to the soil compared to control (without silicon) on two cultivars; Gimeza 10 (salt-sensitive) and Sakha 94 (salt-tolerant) belonging to wheat (Triticum aestivum L.) grown on highly calcareous soil and irrigated from two wells. Physical and chemical analyses of soil before planting are presented in Tables $1 \mathrm{a}$ and $1 \mathrm{~b}$.

TABLE 1a. Physical analysis of Ras- Sudr soil (2011/2012 and 2012/2013 seasons).

\begin{tabular}{|l|c|c|c|c|c|}
\hline Seasons & $\begin{array}{c}\text { Soil depth } \\
(\mathbf{c m})\end{array}$ & $\begin{array}{c}\text { Sand } \\
\mathbf{\%}\end{array}$ & $\begin{array}{c}\text { Silt } \\
\mathbf{\%}\end{array}$ & $\begin{array}{c}\text { Clay } \\
\mathbf{\%}\end{array}$ & Soil texture \\
\hline $2011 / 2012$ & $15-30$ & 74.4 & 18.7 & 6.9 & Sandy loam \\
\hline $2012 / 2013$ & $15-30$ & 68.5 & 28.6 & 2.9 & Sandy loam \\
\hline
\end{tabular}

TABLE 1b. Chemical analysis of Ras- Sudr soil (2011/2012 and 2012/2013 seasons) before sowing.

\begin{tabular}{|l|c|c|c|c|c|c|c|c|c|c|}
\hline Seasons & \multirow{2}{*}{$\mathbf{p H}$} & \multirow{2}{*}{$\begin{array}{c}\mathbf{E C} \\
\mathbf{d s} / \mathbf{m}\end{array}$} & \multicolumn{4}{|c|}{$\begin{array}{c}\text { Soluble cations } \\
\text { (me/L) }\end{array}$} & \multicolumn{4}{c|}{$\begin{array}{c}\text { Soluble anions } \\
\text { (me/L) }\end{array}$} \\
\cline { 4 - 11 } & & & $\mathbf{N a}^{+}$ & $\mathbf{K}^{+}$ & $\mathbf{C a}^{++}$ & $\mathbf{M g}^{++}$ & $\mathbf{C O 3}^{-}$ & $\mathbf{H C O 3}^{-}$ & $\mathbf{C l}^{-}$ & $\mathbf{S O 4}^{-}$ \\
\hline $2011 / 2012$ & 7.94 & 6.27 & 18.00 & 1.60 & 30.00 & 22.50 & 0.00 & 1.25 & 60.11 & 10.74 \\
\hline $2012 / 2013$ & 7.93 & 6.29 & 21.35 & 1.79 & 22.63 & 21.17 & 0.00 & 4.80 & 44.25 & 17.89 \\
\hline
\end{tabular}

Split- split plot design with four replications was used for each experiment. Main plots consisted of the two salinity levels from two different wells (4236 and $7001 \mathrm{ppm}$ ), while sub plots were devoted to the two cultivars (Sakha 94 and Gimeza 10) and silicon levels were applied to soil and arranged in sub-sub plots at 100, 200 and $300 \mathrm{~kg} / \mathrm{fed}$, of potassium silicate $\left(\mathrm{KAlSi}_{3} \mathrm{O}_{8}\right.$ ), compared to control. Silicon was used as $\mathrm{KAlSi}_{3} \mathrm{O}_{8}$, obtained from El-Ahram Company for Mining and Natural Fertilizers. The chemical analysis of the water of the two wells in the two growing seasons is presented in Tables $2 \mathrm{a}$ and $2 \mathrm{~b}$. Data in Table 3 shows the chemical composition of $\mathrm{KAlSi}_{3} \mathrm{O}_{8}$ material as a source of silicon. Si of the experimental soil $(\mathrm{mg} / \mathrm{kg}$ soil) of Ras- Sudr soil after harvest in the two growing seasons was determined according to Snyder (2001) (Table 4).

Egypt. J. Soil Sci. 54, No. 4 (2014) 
TABLE 2a. Chemical analysis of the two wells at Ras-Sudr in 2011/2012.

\begin{tabular}{|c|c|c|c|c|c|c|c|c|c|c|}
\hline \multirow{2}{*}{$\begin{array}{c}\text { Salinity } \\
\text { levels }\end{array}$} & \multirow{2}{*}{$\mathbf{E C ~ d s / m}$} & \multirow{2}{*}{$\begin{array}{c}\text { TDS } \\
\text { p.p.m. }\end{array}$} & \multirow{2}{*}{$\mathbf{P}^{\mathbf{H}}$} & \multicolumn{4}{|c|}{ Cations (meq /L) } & \multicolumn{3}{|c|}{ Anions (meq/L) } \\
\cline { 5 - 11 } & & & $\mathbf{C a}^{++}$ & $\mathbf{M g}^{++}$ & $\mathbf{N a}^{+}$ & $\mathbf{K}^{+}$ & $\mathbf{H C O 3}$ & $\mathbf{C L}^{-}$ & $\mathbf{S O 4}^{=}$ \\
\hline Well No. 1 & 6.62 & 4246 & 7.29 & 16.29 & 22.13 & 30.74 & 0.35 & 1.50 & 30.51 & 37.50 \\
\hline Well No. 2 & 10.94 & 7001 & 7.67 & 16.03 & 17.27 & 67.09 & 0.49 & 1.40 & 60.29 & 38.58 \\
\hline
\end{tabular}

TABLE 2b. Chemical analysis of the two wells at Ras-Sudr in 2012/2013.

\begin{tabular}{|c|c|c|c|c|c|c|c|c|c|c|}
\hline \multirow{2}{*}{$\begin{array}{c}\text { Salinity } \\
\text { levels }\end{array}$} & \multirow{2}{*}{ EC ds/m } & \multirow{2}{*}{$\begin{array}{c}\text { TDS } \\
\mathbf{p p m}\end{array}$} & \multirow{2}{*}{$\mathbf{P}^{\mathbf{H}}$} & \multicolumn{4}{|c|}{ Cations (meq /L) } & \multicolumn{3}{|c|}{ Anions (meq/L) } \\
\cline { 5 - 11 } & & & & $\mathbf{C a + +}$ & $\mathbf{M g + +}$ & $\mathbf{N a +}$ & $\mathbf{K}+$ & $\mathbf{H C O 3}$ & $\mathbf{C L}^{-}$ & $\mathbf{S O 4}^{=}$ \\
\hline Well No. 1 & 7.42 & 4748 & 7.48 & 17.78 & 14.20 & 45.27 & 0.44 & 1.38 & 39.88 & 36.43 \\
\hline Well No. 2 & 11.50 & 7360 & 7.92 & 16.31 & 17.80 & 82.22 & 0.48 & 1.48 & 63.17 & 38.16 \\
\hline
\end{tabular}

TABLE 3. The chemical composition of silicon as $\mathrm{KAISi}_{3} \mathrm{O}_{8}$ by weight percent $\%$.

\begin{tabular}{|l|l|l|l|l|l|l|l|l|l|l|l|}
\hline Component & $\mathrm{SiO}_{2}$ & $\mathrm{Al}_{2} \mathrm{O}_{3}$ & $\mathrm{~K}_{2} \mathbf{O}$ & $\mathbf{N a}_{2} \mathbf{O}$ & $\mathbf{C a O}$ & $\mathbf{F e O}$ & $\mathrm{Fe}_{2} \mathbf{O}_{3}$ & $\mathbf{M g O}$ & $\mathrm{TiO}_{2}$ & $\mathbf{P}_{2} \mathbf{O}_{5}$ & $\mathbf{M n O}$ \\
\hline$\%$ & 72.04 & 14.42 & 4.12 & 3.69 & 1.82 & 1.68 & 1.22 & 0.71 & 0.30 & 0.12 & 0.05 \\
\hline
\end{tabular}

TABLE 4. Silicon content of Ras- Sudr soil (mg/kg soil) after harvest in the two growing seasons.

\begin{tabular}{|l|c|c|c|c|c|c|c|c|}
\hline Treatments & \multicolumn{2}{|c|}{$\begin{array}{c}\text { Control without } \\
\text { (Si) }\end{array}$} & \multicolumn{2}{|c|}{$100 \mathrm{~kg} \mathrm{Si} / \mathrm{fed}$} & \multicolumn{2}{c|}{ 200 kg Si/fed } & \multicolumn{2}{c|}{$300 \mathrm{~kg} \mathrm{Si} / \mathrm{fed}$} \\
\hline Seasons & $\mathbf{2 0 1 1 / 1 2}$ & $\mathbf{2 0 1 2 / 1 3}$ & $\mathbf{2 0 1 1 / 1 2}$ & $\mathbf{2 0 1 2 / 1 3}$ & $\mathbf{2 0 1 1 / 1 2}$ & $\mathbf{2 0 1 2 / 1 3}$ & $\mathbf{2 0 1 1 / 1 2}$ & $\mathbf{2 0 1 2 / 1 3}$ \\
\hline $\mathrm{Si}$ & 9.07 & 9.08 & 19.29 & 19.26 & 22.94 & 22.98 & 31.29 & 31.25 \\
\hline
\end{tabular}

The area of each plot is $2 \times 3 \mathrm{~m}=6 \mathrm{~m}^{2}$, which contains 4 rows $(3 \mathrm{~m}$ length, $50 \mathrm{~cm}$ width). Grains were sown in November, 20, 2011 in the first season and November, 24, 2012 in the second season with seeding rates of $80 \mathrm{~kg} / \mathrm{fed}$, for the two seasons.

Grains of the two wheat cultivars (Sakha 94 and Gimeza 10) were obtained from Agricultural Research Center. The recommended cultural practices of growing wheat plants were applied. At harvest, after 160 days randomized ten plants selected from each plot to determine: plant height $(\mathrm{cm})$, spike length (cm), number of spikelets / spike, weight of 1000 grains (gm), biological yield ( $\mathrm{kg} / \mathrm{fed})$, grain yield ( $\mathrm{kg} / \mathrm{fed})$ and straw yield $(\mathrm{kg} / \mathrm{fed})$. In addition, samples were chosen for the protein analysis. The percentage of nitrogen and protein $(\mathrm{N}$ X6.25) values were calculated as described by A.O.A.C. (1980) and elements: Na and K were determined using flame emissive spectrometry (Page, 1982). All obtained data were statistically analyzed by using analysis of variances according to Snedecor and Cochran (1982) and means were grouped by LSD test at the 5\% probability level. 


\section{Results and Discussion}

\section{A.1- Wheat Yield and Its Components}

Effect of saline irrigation water

Yield and yield components represented by; plant height $(\mathrm{cm})$, spike length (cm), number of spikelets / spike, weight of 1000 grains (g) (Tables 5a and 5b) and biological yield ( $\mathrm{kg} / \mathrm{fed})$, grain yield $(\mathrm{kg} / \mathrm{fed})$, straw yield $(\mathrm{kg} / \mathrm{fed})$ and protein yield (kg/fed) (Fig. 1) as affected by saline irrigation water decreased significantly by increasing salinity from TDS 4236 to $7001 \mathrm{ppm}$. These results were more pronounced in the first season. Decreases in the aforementioned characters were increased with increasing the levels of irrigation salinity due to increasing the soil salinity. These confirmed previously in the results obtained by (Bekheta et al., 2009). The plant height was not significantly affected by both soil salinity, these may be due to the effects of salinity should be much more closely associated with metabolic/nutritional changes within the growing tissues of leaves than in whole or non growing leaf tissues. The obvious results agree with those obtained by (Abd El-Monem, 2010).
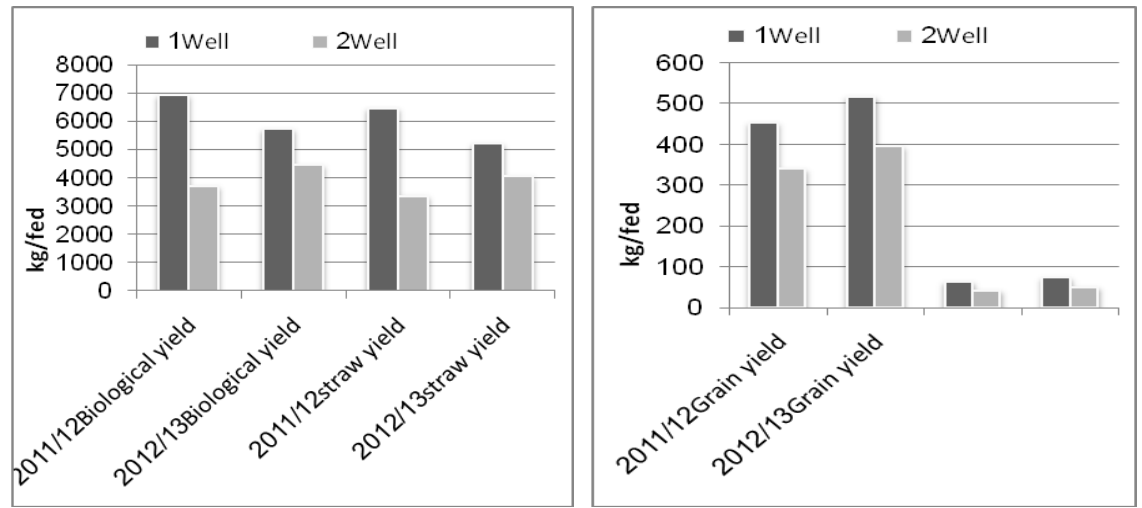

Fig.1. Effect of saline irrigation water on yield in the first and second seasons (2011/2012 and 2012/2013).

\section{Effect of two wheat cultivars}

Data presented in Tables 5a and 5b and Fig. 2, showed that cultivar Gimeza 10 was superior significantly than sakha 94 cultivar in all characters under studied in both seasons. From data it's clear that the two wheat cultivars having contrasting behaviors against salinity Gimeza 10 (salt-sensitive) and sakha 94 (salt-tolerant). This may be due to the increase in plant height, No. of grain /spike and 1000-grains weight which their output caused an increase in grain yield/fed, however, Protein yield was decreased in Gimeza 10. The differences in the grain yield of the two growing seasons were due to the salinity of wells increased in the second season than the first one as shown in Tables $2 \mathrm{a}$ and $2 \mathrm{~b}$. The difference in electric conductivity, in the two growing seasons led to the reduction in yield in the second season than the first one. 
TABLE 5a. Main effect of saline irrigation water, cultivars and silicon on yield components in the first season (2011/2012) .

\begin{tabular}{|c|c|c|c|c|}
\hline Characters & $\begin{array}{c}\text { Plant height } \\
\text { (cm) }\end{array}$ & $\begin{array}{c}\text { Spike length } \\
\text { (cm) }\end{array}$ & $\begin{array}{c}\text { No. of } \\
\text { spikelets/ spike }\end{array}$ & $\begin{array}{c}\text { 1000-grains } \\
\text { weight (g) }\end{array}$ \\
\hline \multicolumn{5}{|c|}{ Saline irrigation water } \\
\hline 4236 ppm & 69.98 & 10.07 & 16.33 & 45.44 \\
\hline $7001 \mathrm{ppm}$ & 65.81 & 9.09 & 13.36 & 40.44 \\
\hline LSD at 5\% & 0.3177 & 0.1588 & 0.5559 & 1.7137 \\
\hline \multicolumn{5}{|c|}{ Cultivars } \\
\hline Sakha 94 & 60.71 & 7.11 & 13.82 & 32.96 \\
\hline Gimeza 10 & 75.08 & 12.06 & 15.88 & 53.16 \\
\hline LSD at 5\% & 1.0591 & 0.6272 & 0.2420 & 1.1566 \\
\hline \multicolumn{5}{|c|}{ Silicon } \\
\hline Control & 56.15 & 8.94 & 13.64 & 29.61 \\
\hline 100KgSi/fed & 69.46 & 9.33 & 14.64 & 42.99 \\
\hline 200KgSi/fed & 72.48 & 9.86 & 15.25 & 47.65 \\
\hline 300KgSi/fed & 73.49 & 10.2 & 15.86 & 52.00 \\
\hline LSD at 5\% & 0.5921 & 0.1932 & 0.2147 & 1.2592 \\
\hline
\end{tabular}

TABLE 5b. Main effect of saline irrigation water, cultivars and silicon on yield components in the first season (2012/2013).

\begin{tabular}{|c|c|c|c|c|}
\hline Characters & $\begin{array}{l}\text { Plant height } \\
\text { (cm) }\end{array}$ & $\begin{array}{l}\text { Spike length } \\
\text { (cm) }\end{array}$ & $\begin{array}{c}\text { No. of } \\
\text { spikelets/ spike }\end{array}$ & $\begin{array}{c}\text { 1000-grains } \\
\text { weight (g) }\end{array}$ \\
\hline \multicolumn{5}{|c|}{ Saline $\quad$ irrigation water } \\
\hline $4748 \mathrm{ppm}$ & 66.19 & 9.93 & 17.06 & 38.59 \\
\hline $7360 \mathrm{ppm}$ & 63.91 & 8.94 & 13.43 & 35.51 \\
\hline LSD at $5 \%$ & n.s & n.s & 1.2706 & n.s \\
\hline \multicolumn{5}{|c|}{ Cultivars } \\
\hline Sakha 94 & 58.93 & 6.76 & 14.12 & 30.50 \\
\hline Gimeza 10 & 71.93 & 12.11 & 16.37 & 43.61 \\
\hline LSD at $5 \%$ & 0.4252 & 0.5922 & 0.0850 & 3.2449 \\
\hline \multicolumn{5}{|c|}{ Silicon } \\
\hline Control & 56.30 & 8.78 & 13.81 & 29.41 \\
\hline $100 \mathrm{~kg} \mathrm{Si} / \mathrm{fed}$ & 64.65 & 9.10 & 15.41 & 35.29 \\
\hline $200 \mathrm{~kg} \mathrm{Si} / \mathrm{fed}$ & 68.55 & 9.69 & 15.71 & 40.56 \\
\hline $300 \mathrm{~kg} \mathrm{Si} / \mathrm{fed}$ & 70.70 & 10.18 & 16.04 & 42.95 \\
\hline LSD at $5 \%$ & 0.8247 & 0.1161 & 0.1483 & 1.3691 \\
\hline
\end{tabular}

Egypt. J. Soil Sci. 54, No. 4 (2014) 

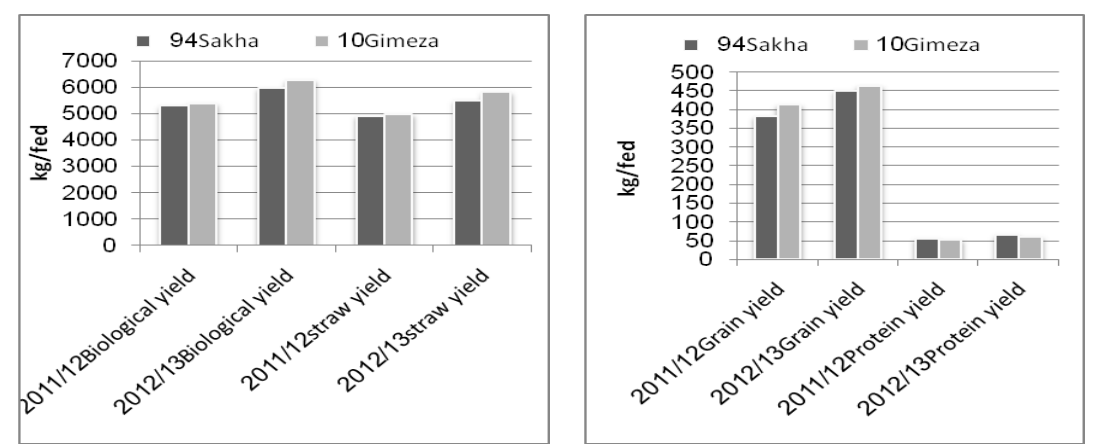

Fig. 2. Effect of wheat cultivars on yield in both seasons (2011/2012 and 2012/2013) .

\section{Effect of silicon}

Data in Tables 5a and 5b and Fig. 3 among all the silicon levels, 200 and 300 $\mathrm{kg} \mathrm{Si} / \mathrm{fed}$, showed better results and increased significantly all characters under study; plant height $(\mathrm{cm})$, spike length $(\mathrm{cm})$, number of spikelets / spike, weight of 1000 grains $(\mathrm{g})$, biological yield ( $\mathrm{kg} / \mathrm{fed})$, grain yield $(\mathrm{kg} / \mathrm{fed})$, straw yield ( $\mathrm{kg} / \mathrm{fed})$ and protein yield ( $\mathrm{kg} / \mathrm{fed})$, in comparison to lower levels $(100 \mathrm{~kg} / \mathrm{fed})$, except the biological yield remained unaffected by Si application in the second season. The improvement of the yield characters were more pronounced at the third level of $\mathrm{Si}(300 \mathrm{~kg} / \mathrm{fed})$ when grown under saline environments than the other Si treatments as well as control. These results are confirmed with Rafiq et al. (1992), Mukkram et al. (2006), Ali et al. (2009) and Saeed et al. (2009). They found that plant height and grain yield for wheat cultivars increased significantly with more silicon levels. This may be due to Si being able to increase resistance of plants against salinity stress which is a major yield limiting factor in arid and semiarid areas. Increase in grain yield was more pronounced in saline environments indicating beneficial effects of $\mathrm{Si}$ application in alleviating salinity stress (Epstein, 2001 and Al-Aghabary et al., 2004).
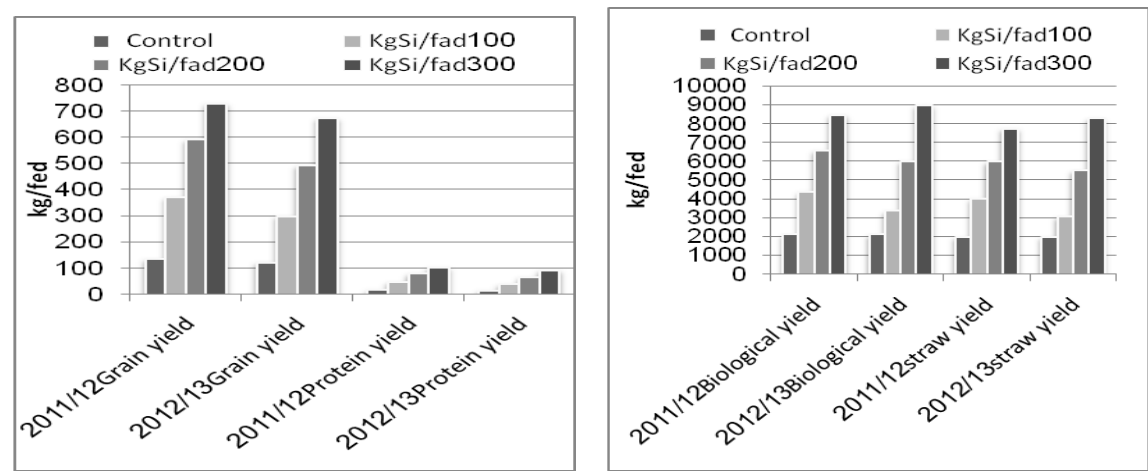

Fig. 3a. Effect of silicon on wheat yield in the first and second seasons (2011/2012 and 2012/2013).

Egypt. J. Soil Sci. 54, No. 4 (2014) 


\section{A.2- First Order Interactions ( Between Two Factors )}

The interaction between wheat cultivars and silicon levels

Data in Tables $6 \mathrm{a}$ and $6 \mathrm{~b}$ showed that the interaction between the two wheat cultivars and silicon levels were significant in all characters under studied except Biological yield in the second season. Concerning the effect of silicon, the highest rate of silicon application $(300 \mathrm{~kg} / \mathrm{fed})$ resulted in pronounced increase on the entire studied yield components compared with the control treatment, especially at the cultivar (Gimeza 10) over than (Sakha 94). These results are confirmed with Rafiq et al. (1992) and Levent et al. (2007), who reported that addition of silicon caused significant recovery from salt stress in wheat plant. A number of possible mechanisms are proposed by which $\mathrm{Si}$ can increase resistance of plants against salinity stress which is a major yield limiting factor in arid and semiarid areas include: stimulation of antioxidant systems in plants, complexation or coprecipitation of toxic metal ions with $\mathrm{Si}$ and compartment of metal ions within plants (Liang et al., 2006). Increase in biological yield was more pronounced in saline environments indicating beneficial effects of $\mathrm{Si}$ application for alleviating salinity stress (Al-Aghabary et al., 2004).

TABLE 6a. Effect of the interaction between cultivars and silicon on wheat yield and yield components (2011/2012 season).

\begin{tabular}{|c|c|c|c|c|c|c|c|c|}
\hline Characters & \begin{tabular}{|c|} 
Plant \\
height \\
$(\mathrm{cm})$
\end{tabular} & \begin{tabular}{|c} 
Spike \\
length \\
$(\mathrm{cm})$
\end{tabular} & \begin{tabular}{|c|} 
No. of \\
spikelets/ \\
spike
\end{tabular} & $\begin{array}{c}\begin{array}{c}1000- \\
\text { grains } \\
\text { weight } \\
\text { (g) }\end{array} \\
\end{array}$ & $\begin{array}{c}\text { Biologic } \\
\text { al yield } \\
\text { (Kg/fed) }\end{array}$ & $\begin{array}{c}\text { Grain } \\
\text { yield } \\
\text { (Kg/fed) }\end{array}$ & $\begin{array}{c}\text { Straw } \\
\text { yield } \\
\text { (kg/fed) }\end{array}$ & $\begin{array}{c}\text { Protein } \\
\text { yield } \\
\text { (Kg/fed) }\end{array}$ \\
\hline $\begin{array}{ll}\text { Sakha } 94 & \\
& \text { Control }\end{array}$ & 53.65 & 6.78 & 12.38 & 26.08 & 1781.23 & 168.10 & 1613.13 & 22.91 \\
\hline $100 \mathrm{KgSi} / \mathrm{fed}$ & 61.10 & 7.03 & 13.68 & 32.78 & 3295.50 & 407.45 & 2888.05 & 56.68 \\
\hline $200 \mathrm{KgSi} / \mathrm{fed}$ & 64.05 & 7.23 & 14.38 & 36.43 & 5218.30 & 585.18 & 4633.12 & 82.94 \\
\hline $300 \mathrm{KgSi} / \mathrm{fed}$ & 64.05 & 7.40 & 14.85 & 36.58 & 5528.13 & 643.85 & 4884.28 & 97.68 \\
\hline $\begin{array}{r}\text { Gimeza } 10 \\
\text { Control }\end{array}$ & 58.65 & 11.10 & 14.90 & 33.15 & 2411.78 & 104.78 & 2307.00 & 12.55 \\
\hline $100 \mathrm{KgSi} / \mathrm{fed}$ & 77.83 & 11.63 & 15.0 & 53.20 & 5427.00 & 334.53 & 5092.47 & 41.17 \\
\hline $200 \mathrm{KgSi} / \mathrm{fed}$ & 80.90 & 12.50 & 16.13 & 58.88 & 7893.00 & 599.98 & 7293.02 & 77.57 \\
\hline $300 \mathrm{KgSi} / \mathrm{fed}$ & 82.93 & 13.00 & 16.88 & 67.43 & 9358.25 & 817.83 & 8540.42 & 107.28 \\
\hline LSD at $5 \%$ & \begin{tabular}{|l|}
0.8378 \\
\end{tabular} & 0.2734 & 1.9373 & \begin{tabular}{|l|}
1.7818 \\
\end{tabular} & 300.7463 & 8.0922 & 252.995 & 1.723 \\
\hline
\end{tabular}

TABLE 6b. Effect of the interaction between cultivars and silicon on wheat yield and yield components (2012/2013 season).

\begin{tabular}{|c|c|c|c|c|c|c|c|}
\hline Characters & $\begin{array}{c}\text { Plant } \\
\text { height } \\
\text { Treatments }\end{array}$ & $\begin{array}{c}\text { Spike } \\
\text { length } \\
\text { (cm) }\end{array}$ & $\begin{array}{c}\text { No. of } \\
\text { spikelets/ } \\
\text { spike }\end{array}$ & $\begin{array}{c}\text { 1000- } \\
\text { grains } \\
\text { weight }(\mathbf{g})\end{array}$ & $\begin{array}{c}\text { Grain } \\
\text { yield } \\
\text { (Kg/fed) }\end{array}$ & $\begin{array}{c}\text { Straw } \\
\text { yield } \\
\text { (kg/fed) }\end{array}$ & $\begin{array}{c}\text { Protein } \\
\text { yield } \\
\text { (Kg/fed) }\end{array}$ \\
\hline $\begin{array}{c}\text { Sakha 94 } \\
\text { Control }\end{array}$ & 54.08 & 6.38 & 12.48 & 26.53 & 154.20 & 1621.1 & 20.78 \\
\hline 100KgSi/fed & 57.83 & 6.58 & 14.35 & 28.90 & 325.93 & 1797.6 & 44.65 \\
\hline 200KgSi/fed & 61.68 & 6.85 & 14.65 & 33.30 & 486.20 & 3186.1 & 68.90 \\
\hline 300KgSi/fed & 62.23 & 7.23 & 15.00 & 33.28 & 561.43 & 3362.7 & 83.92 \\
\hline $\begin{array}{c}\text { Gimeza 10 } \\
\text { Control }\end{array}$ & 58.53 & 11.18 & 15.15 & 32.30 & 91.28 & 2319.8 & 10.51 \\
\hline 100KgSi/fed & 71.48 & 11.63 & 16.48 & 41.68 & 273.40 & 4275.6 & 33.12 \\
\hline 200KgSi/fed & 75.53 & 12.53 & 16.78 & 47.83 & 501.08 & 5697.0 & 63.41 \\
\hline 300KgSi/fed & 79.18 & 13.13 & 17.08 & 52.63 & 786.25 & 7467.1 & 100.65 \\
\hline LSD at 5\% & 1.1671 & 0.1643 & 0.2099 & 1.9373 & 22.5101 & 215.110 & 2.726 \\
\hline
\end{tabular}

$\left(\right.$ Feddan $\left.=4200 \mathrm{~m}^{2}\right)$.

Egypt. J. Soil Sci. 54, No. 4 (2014) 
The interaction between saline irrigation water and silicon levels

Data in Tables $7 \mathrm{a}$ and $7 \mathrm{~b}$ showed that the interaction between saline irrigation water and silicon levels were significant in all characters under studied except spike length in the first season and plant height and Biological yield in the second season which were insignificant. The application of 100 up to $300 \mathrm{~kg} \mathrm{Si} /$ fed increased the yield and yield components in both seasons under two levels of saline irrigation water. These results were in agreed with those reported by Hanafy Ahmed et al. (2002). The best treatment in all characters under the studied was the plant irrigated by ( 4236 and $4748 \mathrm{ppm}$ ) and silicon with the rate of $300 \mathrm{~kg} / \mathrm{fed}$ in the both seasons. The adverse effects of salinity as regards the yield parameters were significant alleviated by $\mathrm{Si}$ supplement. These results are in agreement with those reported by Ali et al. (2009) and Abd El-Monem (2010) who found that supplementary silicon, resulted in significant increase in yield of wheat grown under saline conditions. They found that the yield decreased with increasing salinity in the absence of silicon. However, addition of Si caused significant recovery from salt stress. In the analysis of the beneficial effect of Si under saline yield condition, it is important to consider the role of $\mathrm{Si}$ in plant water status because the initial reduction of plant growth and yield after imposition is due to the osmotic effect of salt (Al-Aghabary et al., 2004).

TABLE 7a. Effect of the interaction between saline irrigation water and silicon on wheat yield and yield components (2011/2012 season).

\begin{tabular}{|c|c|c|c|c|c|c|c|}
\hline Characters & $\begin{array}{c}\text { Plant } \\
\text { height } \\
\text { (cm) }\end{array}$ & $\begin{array}{c}\text { No. of } \\
\text { spikelets/ } \\
\text { spike }\end{array}$ & $\begin{array}{c}\text { 1000- } \\
\text { grains } \\
\text { weight }(\mathbf{g})\end{array}$ & $\begin{array}{c}\text { Biological } \\
\text { yield } \\
\text { (Kg/fed) }\end{array}$ & $\begin{array}{c}\text { Grain } \\
\text { yield } \\
\text { (Kg/fed) }\end{array}$ & $\begin{array}{c}\text { Straw } \\
\text { yield } \\
\text { (kg/fed) }\end{array}$ & $\begin{array}{c}\text { Protein } \\
\text { yield } \\
\text { (Kg/fed) }\end{array}$ \\
\hline I $1 \quad$ Control & 58.83 & 15.23 & 33.45 & 2362.75 & 146.23 & 2216.52 & 19.83 \\
\hline $100 \mathrm{KgSi} /$ fed & 71.15 & 15.83 & 45.68 & 4926.00 & 441.23 & 4484.77 & 59.34 \\
\hline 200KgSi/fed & 74.70 & 16.70 & 50.28 & 7567.80 & 709.53 & 6858.27 & 100.17 \\
\hline 300KgSi/fed & 75.23 & 17.58 & 52.38 & 8153.38 & 778.48 & 7374.90 & 116.08 \\
\hline I 2 Control & 53.48 & 12.05 & 25.78 & 1830.25 & 126.65 & 1703.60 & 15.63 \\
\hline 100KgSi/fed & 67.78 & 13.45 & 40.30 & 3796.50 & 300.75 & 3495.75 & 38.51 \\
\hline 200KgSi/fed & 70.25 & 13.80 & 45.03 & 5543.50 & 475.63 & 5067.87 & 60.34 \\
\hline 300KgSi/fed & 71.75 & 14.15 & 51.63 & 6733.00 & 683.20 & 6049.80 & 88.88 \\
\hline LSD at 5\% & 0.8378 & 0.3038 & 1.7818 & 300.7463 & 8.0922 & 252.995 & 1.722 \\
\hline
\end{tabular}

Which $\mathrm{I} 1=$ saline irrigation water $4236 \mathrm{ppm}, \mathrm{I} 2=$ saline irrigation water $7001 \mathrm{ppm}$ in the first season while in the second season was $\mathrm{I} 1=4748 \mathrm{ppm}$ and $\mathrm{I} 2=7360 \mathrm{ppm}$, Tables $2 \mathrm{a}$ and $2 \mathrm{~b}$.

TABLE 7b. Effect of the interaction between saline irrigation water and silicon on wheat yield and yield components (2012/2013 season).

\begin{tabular}{|c|c|c|c|c|c|c|}
\hline Treatments & $\begin{array}{c}\text { Spike } \\
\text { length } \\
(\mathrm{cm})\end{array}$ & $\begin{array}{c}\text { No. of } \\
\text { spikelets/ } \\
\text { spike } \\
\end{array}$ & $\begin{array}{c}1000- \\
\text { grains } \\
\text { weight }(\mathrm{g})\end{array}$ & $\begin{array}{c}\text { Grain } \\
\text { yield } \\
\text { (Kg/fed) }\end{array}$ & $\begin{array}{c}\text { Straw yield } \\
\text { (kg/fed) }\end{array}$ & $\begin{array}{c}\text { Protein } \\
\text { yield } \\
(\text { Kg/fed })\end{array}$ \\
\hline I 1 Control & 9.08 & 15.30 & 32.53 & 134.48 & 2342.1 & 17.71 \\
\hline $100 \mathrm{KgSi} / \mathrm{fed}$ & 9.43 & 17.30 & 35.98 & 374.35 & 3147.9 & 49.69 \\
\hline $200 \mathrm{KgSi} / \mathrm{fed}$ & 10.28 & 17.63 & 42.18 & 592.90 & 4948.2 & 83.51 \\
\hline $300 \mathrm{KgSi} / \mathrm{fed}$ & 10.93 & 18.00 & 43.70 & 716.08 & 5754.1 & 104.69 \\
\hline I 2 Control & 8.48 & 12.33 & 26.30 & 111.00 & 1598.6 & 13.58 \\
\hline $100 \mathrm{KgSi} / \mathrm{fed}$ & 8.78 & 13.53 & 34.60 & 224.98 & 2926.3 & 28.08 \\
\hline $200 \mathrm{KgSi} / \mathrm{fed}$ & 9.10 & 13.80 & 38.95 & 394.38 & 3934.9 & 48.87 \\
\hline $300 \mathrm{KgSi} / \mathrm{fed}$ & 9.43 & 14.08 & 42.20 & 631.60 & 5075.7 & 79.88 \\
\hline LSD at $5 \%$ & 0.164 & 0.209 & 1.937 & 22.510 & 215.110 & 2.726 \\
\hline
\end{tabular}

Egypt. J. Soil Sci. 54, No. 4 (2014) 
The interaction between irrigation water salinity and wheat cultivars

From analysis of variances (ANOVA Tables), the interaction between saline irrigation water and wheat cultivars were insignificantly in all characters studied in both seasons.

\section{A.3- Second order interaction (between three factors)}

The interaction between saline irrigation water, wheat cultivars and silicon levels application:

The interaction between two levels of saline irrigation water, two wheat cultivars and different silicon levels was significant in all characters under studied, plant height $(\mathrm{cm})$, spike length $(\mathrm{cm})$, number of spikelets / spike, weight of 1000 grains $(\mathrm{g})$, biological yield $(\mathrm{kg} / \mathrm{fed})$, grain yield $(\mathrm{kg} / \mathrm{fed})$, straw yield (kg/fed) and protein yield ( $\mathrm{kg} / \mathrm{fed})$, except spike length in the first season and plant height and biological yield in the second season which were insignificant. Maximum values were obtained by application of $300 \mathrm{~kg} \mathrm{Si} / \mathrm{fed}$, on wheat cultivar Gimeza, 10 and irrigated by low irrigation water salinity (4236 and 4748 ppm) in both seasons (Tables $8 \mathrm{a}$ and $8 b$ ).

TABLE 8a. Effect of the interaction between saline irrigation water, cultivars and silicon on wheat yield and yield components (2011/2012 season).

\begin{tabular}{|c|c|c|c|c|c|c|c|c|}
\hline \multicolumn{2}{|c|}{ Treatments } & $\begin{array}{c}\text { Plant } \\
\text { height } \\
(\mathrm{cm})\end{array}$ & \begin{tabular}{|c|} 
No. of \\
spikelets/ \\
spike
\end{tabular} & $\begin{array}{c}\text { 1000- } \\
\text { grains } \\
\text { weight } \\
\text { (g) }\end{array}$ & $\begin{array}{c}\text { Biological } \\
\text { yield } \\
\text { (Kg/fed) }\end{array}$ & $\begin{array}{c}\text { Grain } \\
\text { yield } \\
\text { (Kg/fed }\end{array}$ & $\begin{array}{c}\text { Straw } \\
\text { yield } \\
\text { (kg/fed) }\end{array}$ & $\begin{array}{c}\text { Protein } \\
\text { yield } \\
\text { (Kg/fed) }\end{array}$ \\
\hline \multirow[t]{8}{*}{$\begin{array}{l}\text { 4236p } \\
p m\end{array}$} & $\begin{array}{l}\text { Sakha } 94 \\
\text { Control }\end{array}$ & 56.3 & 13.6 & 27.6 & 1872.5 & 180.3 & 1692.2 & 25.32 \\
\hline & $100 \mathrm{KgSi} / \mathrm{fed}$ & 61.6 & 13.9 & 34.8 & 4272.5 & 425.2 & 3847.3 & 60.17 \\
\hline & $200 \mathrm{KgSi} / \mathrm{fed}$ & 65.5 & 14.8 & 38.7 & 6502.1 & 689.8 & 5812.3 & 99.33 \\
\hline & $300 \mathrm{KgSi} / \mathrm{fed}$ & 64.4 & 15.5 & 36.8 & 6112.8 & 640.0 & 5472.8 & 102.42 \\
\hline & $\begin{array}{r}\text { Gimeza10 } \\
\text { Control }\end{array}$ & 61.4 & 16.9 & 39.4 & 2853.1 & 112.2 & 2740.9 & 14.34 \\
\hline & $100 \mathrm{KgSi} / \mathrm{fed}$ & 80.8 & 17.8 & 56.6 & 5579.5 & 457.3 & 5104.2 & 58.52 \\
\hline & $200 \mathrm{KgSi} / \mathrm{fed}$ & 83.9 & 18.7 & 61.9 & 8633.5 & 729.3 & 6104.2 & 102.00 \\
\hline & $300 \mathrm{KgSi} / \mathrm{fed}$ & 86.1 & 19.7 & 68.0 & 10194.0 & 916.9 & 9277.1 & 129.74 \\
\hline \multirow[t]{8}{*}{$\begin{array}{l}7001 \mathrm{p} \\
\mathrm{pm}\end{array}$} & $\begin{array}{l}\text { Sakha } 94 \\
\text { Control }\end{array}$ & 51.0 & 11.2 & 24.6 & 1690.0 & 155.9 & 1534.1 & 20.50 \\
\hline & $100 \mathrm{KgSi} / \mathrm{fed}$ & 60.7 & 13.5 & 30.8 & 2318.5 & 389.7 & 1928.8 & 53.19 \\
\hline & $200 \mathrm{KgSi} / \mathrm{fed}$ & 62.7 & 14.0 & 34.2 & 3934.5 & 480.6 & 3453.9 & 66.55 \\
\hline & $300 \mathrm{KgSi} / \mathrm{fed}$ & 63.8 & 14.2 & 36.4 & 4943.5 & 647.7 & 4295.8 & 92.94 \\
\hline & $\begin{array}{r}\text { Gimeza } 10 \\
\text { Control }\end{array}$ & 55.9 & 12.9 & 26.9 & 1970.5 & 97.4 & 1873.1 & 10.75 \\
\hline & $100 \mathrm{KgSi} / \mathrm{fed}$ & 74.9 & 13.5 & 49.8 & 5274.5 & 211.8 & 5062.7 & 23.82 \\
\hline & $200 \mathrm{KgSi} / \mathrm{fed}$ & 77.9 & 13.6 & 55.9 & 7152.5 & 470.7 & 6681.8 & 54.13 \\
\hline & $300 \mathrm{KgSi} / \mathrm{fed}$ & 79.8 & 14.1 & 66.9 & 8522.5 & 718.7 & 7803.3 & 84.82 \\
\hline & $\mathrm{LSD}$ at $5 \%$ & 1.184 & 0.429 & 2.514 & 425.319 & 13.360 & 505.989 & 2.425 \\
\hline
\end{tabular}


TABLE 8b. Effect of the interaction between saline irrigation water, cultivars and silicon on wheat yield and yield components (2012/2013 season).

\begin{tabular}{|c|c|c|c|c|c|c|c|}
\hline \multicolumn{2}{|c|}{ Treatments } & \multirow{2}{*}{$\begin{array}{c}\begin{array}{c}\text { Spike } \\
\text { length } \\
(\mathbf{c m})\end{array} \\
6.6\end{array}$} & \multirow{2}{*}{\begin{tabular}{|c|}
$\begin{array}{c}\text { No. of } \\
\text { spikelets/ } \\
\text { spike }\end{array}$ \\
13.5 \\
\end{tabular}} & \multirow{2}{*}{$\begin{array}{c}\begin{array}{c}\text { 1000- } \\
\text { grains } \\
\text { weight } \\
\text { (g) }\end{array} \\
28.4\end{array}$} & \multirow{2}{*}{$\begin{array}{c}\begin{array}{c}\text { Grain } \\
\text { yield } \\
\text { Kg/fed }\end{array} \\
164.7\end{array}$} & \multirow{2}{*}{$\begin{array}{c}\begin{array}{c}\text { Straw } \\
\text { yield } \\
\text { kg/fed }\end{array} \\
1770.3\end{array}$} & \multirow{2}{*}{$\begin{array}{c}\begin{array}{c}\text { Protein } \\
\text { yield } \\
\text { Kg/fed }\end{array} \\
22.80\end{array}$} \\
\hline 4748ppm & $\begin{array}{r}\text { Sakha } 94 \\
\text { Control }\end{array}$ & & & & & & \\
\hline & $100 \mathrm{KgSi} / \mathrm{fed}$ & 6.7 & 15.1 & 29.8 & 371.1 & 1890.4 & 51.83 \\
\hline & $200 \mathrm{KgSi} / \mathrm{fed}$ & 7.1 & 15.4 & 35.6 & 610.5 & 4159.5 & 88.21 \\
\hline & $300 \mathrm{KgSi} / \mathrm{fed}$ & 7.5 & 15.9 & 32.2 & 581.4 & 3612.8 & 90.69 \\
\hline & $\begin{array}{r}\text { Gimeza } 10 \\
\text { Control }\end{array}$ & 11.6 & 17.2 & 36.7 & 104.3 & 2913.9 & 12.61 \\
\hline & $100 \mathrm{KgSi} / \mathrm{fed}$ & 12.2 & 19.6 & 42.2 & 377.6 & 4403.4 & 47.56 \\
\hline & $200 \mathrm{KgSi} / \mathrm{fed}$ & 13.5 & 19.9 & 48.7 & 575.4 & 5736.8 & 157.64 \\
\hline & $300 \mathrm{KgSi} / \mathrm{fed}$ & 14.4 & 20.1 & 55.2 & 850.8 & 7895.3 & 118.68 \\
\hline \multirow[t]{8}{*}{$\begin{array}{l}7360 \\
\text { ppm }\end{array}$} & $\begin{array}{r}\text { Sakha } 94 \\
\text { Control }\end{array}$ & 6.2 & 11.5 & 24.7 & 143.7 & 1471.8 & 18.75 \\
\hline & $100 \mathrm{KgSi} / \mathrm{fed}$ & 6.5 & 13.7 & 28.1 & 280.8 & 1704.7 & 37.47 \\
\hline & $200 \mathrm{KgSi} / \mathrm{fed}$ & 6.7 & 13.9 & 31.0 & 361.9 & 2212.6 & 49.59 \\
\hline & $300 \mathrm{KgSi} / \mathrm{fed}$ & 6.9 & 14.1 & 34.4 & 541.5 & 3112.6 & 77.15 \\
\hline & $\begin{array}{r}\text { Gimeza } 10 \\
\text { Control }\end{array}$ & 10.8 & 13.2 & 27.9 & 78.3 & 1725.7 & 8.42 \\
\hline & $100 \mathrm{KgSi} / \mathrm{fed}$ & 11.1 & 13.4 & 41.2 & 169.2 & 4147.8 & 18.69 \\
\hline & $200 \mathrm{KgSi} / \mathrm{fed}$ & 11.6 & 13.7 & 46.9 & 426.8 & 5657.2 & 48.01 \\
\hline & $300 \mathrm{KgSi} / \mathrm{fed}$ & 11.9 & 14.1 & 50.1 & 721.8 & 7038.8 & 82.62 \\
\hline \multicolumn{2}{|c|}{ LSD at $5 \%$} & 0.2322 & 0.2968 & 2.7398 & 31.8241 & 430.220 & 3.855 \\
\hline
\end{tabular}

\section{B. Chemical composition of wheat}

Effect of the interaction among saline irrigation water, silicon levels application of two wheat cultivars

Data in Fig. 4a and $4 \mathrm{~b}$ and Table 9 show that the effect of the interaction among saline irrigation water, Silicon levels application of two wheat cultivars (Sakha 94) and Gimeza 10) was significant in $\mathrm{Na}^{+}(\mathrm{mg} / \mathrm{g}), \mathrm{K}^{+}(\mathrm{mg} / \mathrm{g})$, protein content and $\left(\mathrm{K}^{+} / \mathrm{Na}^{+}\right.$ratio), in both seasons except potassium in the second season which was insignificant. Sodium content was higher in wheat cultivars grown under saline irrigation water; however Si application significantly reduced Na content in grain of two wheat cultivars. Potassium content was lower in grain wheat grown under high saline irrigation water $(8.21$ and $8.02 \mathrm{mg} / \mathrm{g})$ than those grown in low saline irrigation water (12.92 and $12.95 \mathrm{mg} / \mathrm{g})$ in the both season, respectively. Liang et al. (2007) reported a significant increase in $\mathrm{K}$ uptake and decrease in Na uptake under salt stress when Si was included because of increasing activity of plasma membrane H-ATPase. Potassium/Sodium ratio was lower significantly under high salinity irrigation water when $\mathrm{Si}$ was not applied. Increased $\mathrm{K}$ content and reduced $\mathrm{Na}$ in grains of both cultivars may be one of the possible mechanisms of increasing salinity tolerance by Si application in wheat plants.

Silicon is known also to reduce $\mathrm{Na}$ uptake (Matichenkov and Kosobrukhov, 2004). Silicon application enhanced K/Na selectivity ratio in wheat cultivars thus enhancing biological and grain yields. Silicon when deposited in exodermises 
and endodermis of roots reduced Na uptake in plants (Gong et al., 2003). These results were agreed with those reported by Hanafy Ahmed et al. (2008). Nitrate nitrogen was accumulated in the Sakha 94 cultivar plants grown under saline conditions especially at moderately saline (4236 and 4748ppm) and strongly saline irrigation (7001 and $7360 \mathrm{ppm}$ ), respectively in both seasons compared to Gimeza 10. It might be due to an adaptation mechanism developed by the plants to overcome osmotic stress caused by salinity while further decrease in nitrate nitrogen might be related to the antagonistic relation between toxic $\mathrm{Cl}^{-}$and $\mathrm{NO}^{-}$ ${ }_{3}$, (Sharma et al., 2005).

The exclusion of $\mathrm{Na}^{+}$ions and a higher $\mathrm{K}$ : $\mathrm{Na}$ ratio in wheat cultivars grown under saline irrigation water has been confirmed as important selection criteria for salt tolerance (Hellal et al., 2012). Application of Si increased significantly the contents of $\mathrm{N}, \mathrm{K}$ and the $\mathrm{K}$ : $\mathrm{Na}$ ratio and decreased $\mathrm{Na}$ ion contents of salt affected plants. Therefore, the results shown in (Table 8) agree with faba bean experimentations by (Hellal et al., 2012) which indicated that salt tolerance is associated with an enhanced K: Na discrimination trait. The ability of plant to limit $\mathrm{Na}$ transport into the shoot is critically importance for the maintenance of high growth rates and protection of the metabolic processes in elongation cells from the toxic effects of $\mathrm{Na}^{+}$(Ali et al., 2012).
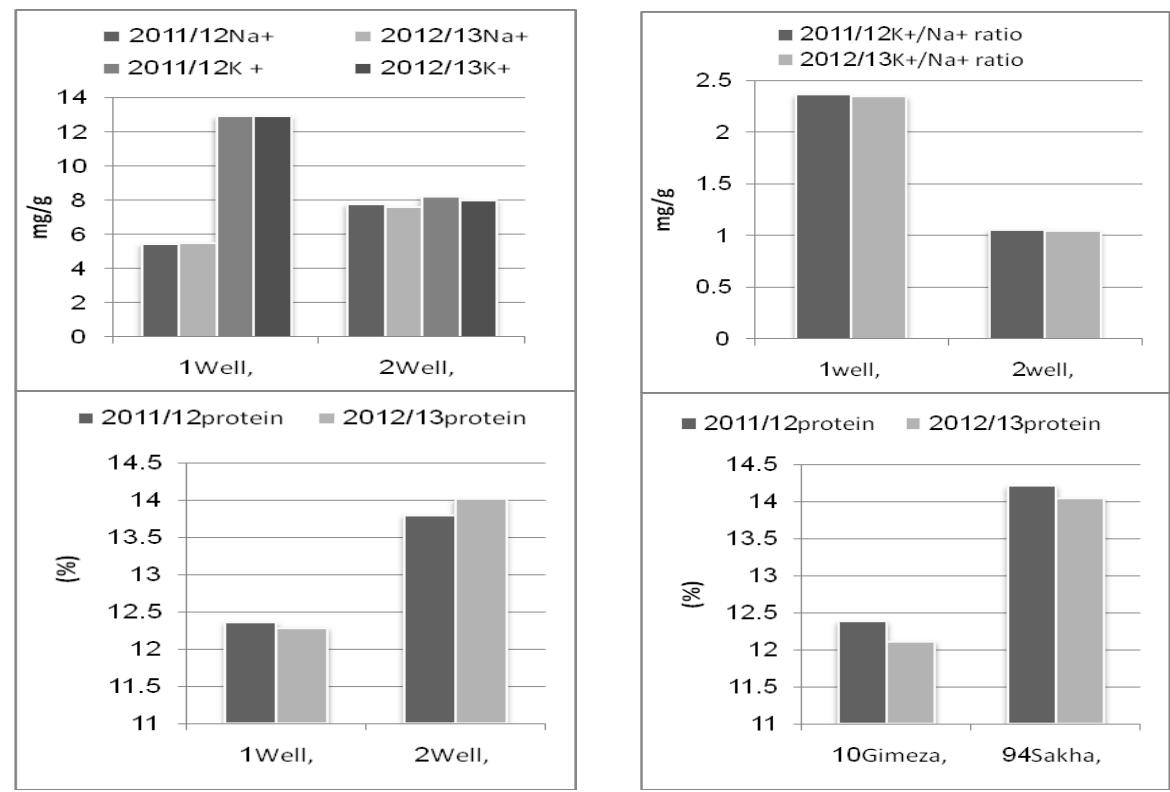

Fig. 4a. Main effect of saline irrigation water and two cultivars on chemical composition $\mathrm{Na}^{+}, \mathrm{K}^{+}, \mathrm{K}^{+} / \mathrm{Na}^{+}$ratio and protein content of two wheat cultivars in the both seasons.

Well, $1=4236$ and 4748 ppm saline irrigation water in both seasons and Well, $2=7001$ and 7360 ppm saline irrigation water in both seasons

Egypt. J. Soil Sci. 54, No. 4 (2014) 

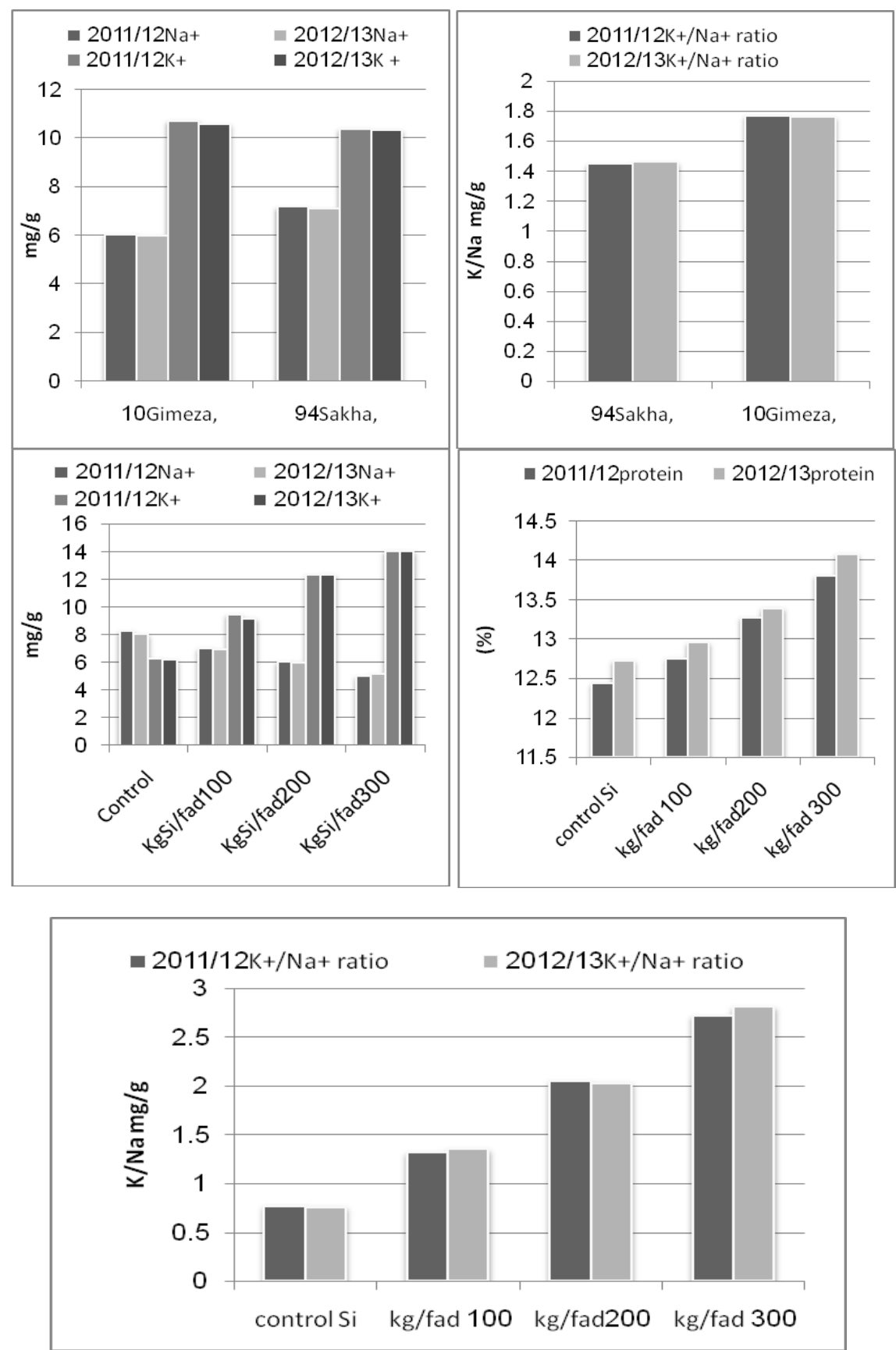

Fig. 4b. Main effect of Si application and two cultivars on chemical composition $\mathrm{Na}^{+}$, $\mathrm{K}^{+}, \mathrm{K}^{+} / \mathrm{Na}^{+}$ratio and protein content of two wheat cultivars in the both seasons. 
TABLE 9. Effect of interaction between saline irrigation water, cultivars and silicon on chemical components of two wheat cultivars grains.

\begin{tabular}{|c|c|c|c|c|c|c|c|c|c|}
\hline \multicolumn{2}{|c|}{ Characters } & \multicolumn{2}{|c|}{$\begin{array}{c}\mathrm{Na}^{+} \\
(\mathrm{mg} / \mathrm{g})\end{array}$} & \multicolumn{2}{|c|}{$\begin{array}{c}\mathbf{K}^{+} \\
(\mathrm{mg} / \mathrm{g})\end{array}$} & \multicolumn{2}{|c|}{$\begin{array}{c}\mathrm{K}^{+} / \mathrm{Na}^{+} \\
\text {ratio }\end{array}$} & \multicolumn{2}{|c|}{$\begin{array}{c}\% \text { Protein } \\
\text { content }\end{array}$} \\
\hline \multicolumn{2}{|c|}{ Treatments } & $\begin{array}{c}2011 / \\
2012\end{array}$ & $\begin{array}{c}2012 / \\
2013\end{array}$ & $\begin{array}{l}2011 / \\
2012\end{array}$ & $\begin{array}{c}2012 / \\
2013\end{array}$ & $\begin{array}{l}2011 / \\
2012\end{array}$ & $\begin{array}{c}2012 / \\
2013\end{array}$ & $\begin{array}{c}2011 / \\
2012\end{array}$ & $\begin{array}{c}2012 / \\
2013\end{array}$ \\
\hline \multirow{8}{*}{$\begin{array}{c}(4236 \text { and } \\
4748) \\
\text { ppm }\end{array}$} & \begin{tabular}{|c|} 
Sakha,94 \\
Control
\end{tabular} & 5.75 & 5.52 & 6.88 & 6.43 & 1.19 & 1.16 & 13.1 & 13.2 \\
\hline & $\begin{array}{l}100 \mathrm{KgSi} / \\
\text { fed }\end{array}$ & 5.66 & 5.46 & 8.67 & 7.76 & 1.53 & 1.42 & 13.4 & 13.7 \\
\hline & $\begin{array}{l}200 \mathrm{KgSi} / \\
\text { fed }\end{array}$ & 5.08 & 5.17 & 9.29 & 9.49 & 1.82 & 1.83 & 13.7 & 13.9 \\
\hline & $\begin{array}{l}300 \mathrm{KgSi} / \\
\text { fed }\end{array}$ & 4.37 & 4.92 & 9.64 & 10.30 & 2.21 & 2.09 & 14.3 & 14.4 \\
\hline & $\begin{array}{c}\text { Gimeza, } 10 \\
\text { Control }\end{array}$ & 6.61 & 6.59 & 4.60 & 4.55 & 0.69 & 0.69 & 10.7 & 11.1 \\
\hline & $\begin{array}{c}100 \mathrm{KgSi} / \\
\text { fed }\end{array}$ & 6.06 & 6.20 & 6.91 & 6.93 & 1.14 & 1.11 & 11.1 & 11.3 \\
\hline & $\begin{array}{l}200 \mathrm{KgSi} / \\
\text { fed }\end{array}$ & 5.73 & 5.69 & 9.22 & 8.69 & 1.60 & 1.53 & 11.3 & 11.5 \\
\hline & $\begin{array}{l}300 \mathrm{KgSi} / \\
\text { fed }\end{array}$ & 4.43 & 4.53 & 10.54 & 10.03 & 2.38 & 2.21 & 11.5 & 11.8 \\
\hline \multirow{8}{*}{$\begin{array}{l}\text { (7001 } \\
\text { and } \\
7836) \\
\text { ppm }\end{array}$} & $\begin{array}{c}\text { Sakha,94 } \\
\text { Control }\end{array}$ & 9.06 & 9.19 & 6.92 & 7.13 & 0.76 & 0.77 & 13.8 & 14.1 \\
\hline & $\begin{array}{l}100 \mathrm{KgSi} / \\
\text { fed }\end{array}$ & 6.99 & 6.74 & 11.10 & 10.84 & 1.58 & 1.60 & 14.1 & 14.2 \\
\hline & $\begin{array}{l}200 \mathrm{KgSi} / \\
\text { fed }\end{array}$ & 6.42 & 6.50 & 15.87 & 15.81 & 2.47 & 2.43 & 14.5 & 14.4 \\
\hline & $\begin{array}{l}300 \mathrm{KgSi} / \\
\text { fed }\end{array}$ & 5.18 & 5.06 & 17.52 & 17.08 & 3.38 & 3.37 & 15.6 & 16.1 \\
\hline & $\begin{array}{c}\text { Gimeza, } 10 \\
\text { Control }\end{array}$ & 11.74 & 11.01 & 6.72 & 6.78 & 0.57 & 0.61 & 12.1 & 12.7 \\
\hline & $\begin{array}{l}100 \mathrm{KgSi} / \\
\text { fed }\end{array}$ & 9.54 & 9.54 & 11.41 & 11.39 & 1.19 & 1.19 & 12.6 & 12.8 \\
\hline & $\begin{array}{l}200 \mathrm{KgSi} / \\
\text { fed }\end{array}$ & 7.16 & 7.27 & 15.05 & 15.65 & 2.10 & 2.15 & 13.7 & 13.8 \\
\hline & $\begin{array}{l}300 \mathrm{KgSi} / \\
\text { fed }\end{array}$ & 6.35 & 6.15 & 18.75 & 18.90 & 2.95 & 3.07 & 13.9 & 14.2 \\
\hline \multicolumn{2}{|c|}{ LSD at $5 \%$} & 0.413 & 0.400 & 1.126 & n.s & ------ & ------ & 0.228 & 0.137 \\
\hline
\end{tabular}

\section{Conclusion}

It was concluded from the current field study that using silicon is beneficial to mitigate salinity stress under a wide range of field conditions. The results of this study highlight the role of silicon in improving wheat cultivars yield under low or high saline irrigation water. We suggest that under low saline irrigation water, silicon should be treated soil by concentration $300 \mathrm{~kg} \mathrm{Si} / \mathrm{fed}$, increased

Egypt. J. Soil Sci. 54, No. 4 (2014) 
significantly grain yield/feddan to minimize the hazardous effects of salinity on yield of wheat cultivars. Si improvement in wheat yield was associated with reduced $\mathrm{Na}^{+}$uptake and increased $\mathrm{K}^{+}$uptake resulting an improved $\mathrm{K}^{+} / \mathrm{Na}^{+}$ratio in seed cultivars; Gimeza 10, performed Sakha 94 under salinity stress. In general, silicon at the rate of $300 \mathrm{~kg} / \mathrm{fed}$ and irrigated by well (4236 and 4748 ppm moderate level of salinity), encourage the farmers to use silicon to enhance the salt tolerance of wheat that is mediated via improvement in yield and yield components.

Acknowledgement: The author is grateful to Dr. Yousry Mohamed Mahmoud Ibrahim, the owner of El-Ahram Company for Mining and Natural Fertilizers, for support and his encouragement.

\section{References}

Abd El-Monem, M.Sh. (2010) Improvement growth and yield of wheat plants grown under salinity stress by using silicon. J. of American Sci. 6(11): 559-566.

Agurie, S., Agata, W., Kubota, F. and Kaufman, P.B. (1992) Physiological role of silicon in photosynthesis and dry matter production in rice plants. J. Crop Sci. 61: 200-206.

Akram, M.S., Athar, H.R. and Ashraf, M. (2007) Improving growth and yield of sunflower (Helianthus annuus L.) by foliar application of potassium hydroxide (KOH) under salt stress. Pak. J. Bot. 39: 2223-2230.

Al-Aghabary, K., Zhu, Z. and Shi, Q. (2004) Influence of silicon supply on chlorophyll content, chlorophyll fluorescence and antioxidative enzyme activities in tomato plants under salt stress. J. Plant Nutr. 27: 2101-2115.

Ali, A., Basra, S. M. A., Ahmad, R. and Wahid, A. (2009) Optimizing silicon application to improve salinity tolerance in wheat. Soil \& Environ. 28(2): 136-144.

Ali, A., Basra, S. M. A., Lqbal, J., Hussain, S., Subhani, M. N., Sarwar, M. and Ahmed, M. (2012) Augmenting the salt tolerance in wheat (Triticum aestivum L.) through exogenously applied silicon. African J. of Biotechnology 11(3): 642- 649.

Al-Rawahy, S.A., Al-Dhuhli, H.S., Prathapar, S. and AbdelRahman, H. (2011) Mulching material impact on yield, soil moisture and salinity in saline-irrigated sorghum plots. International J. of Agric. Res. 6(1): 755-81.

Association of Official Agricultural Chemists (A.O.A.C.) (1980) In: "Official Methods of Analysis", $13^{\text {th }}$ ed ., The A.O.A.C., Washington D.C., U.S.A.

Ashraf, M. and Harris, P.J.C. (2004) Potential biochemical indicators of salinity tolerance in plants. Plant Sci. 166: 3-16.

Awada, S., Campbell, W.F., Dudley, L.M., Jurinak, J.J. and Khan, M.A. (1995) Interactive effects of sodium chloride, sodium sulfate, calcium sulfate, and calcium chloride on snap bean growth, photosynthesis and ion uptake. J. Plant Nutr. 18: 889900 .

Egypt. J. Soil Sci. 54, No. 4 (2014) 
Bekheta, M.A., Abdelhamid, M.T. and El-Morsi, A.A. (2009) Physiological response of Vicia faba to prohexadione-calcium under saline conditions. Planta Daninha 27: 769-779.

Epstein, E. (2001) Silicon in plants: facts vs. concepts. In: "Silicon in Agriculture", L. E. Datnoff, G.H. Snyder and G.H. Korndorfer (Ed.), pp. 1-16, Elsevier, Amsterdam.

Gong, H.J., Chen, K. M., Chen, G. C. Wang, S.M. and Zhang, C.L. (2003) Effect of silicon on growth of wheat under drought. J. of Plant Nutrition 5: 1055-1063.

Grattan, S.R. and Grieve, C.M. (1999) Salinity-mineral nutrient relations in horticultural crops. Scentia Horticulturae 78: 127-157.

Hanafy Ahmed, A.H., Higazy, M.A., El-Shafey, Y.H. and Moussa, S.F. (2002) Effect of salinity, silicon and porline on the growth, yield and chemical composition of wheat plant. Proc. $2^{\text {nd }}$ Cong. Recent Technol., Fac. Agric., Cairo Univ., 28-30 October, pp: 965-978.

Hanafy, Ahmed, A.H., Harb, E.M., Hgazy, M.A. and Moran, Sh. H. (2008) Effect of silicon and boron foliar application on wheat plants grown under saline soil conditions. International J. of Agricultural Res. 3(1):1-26.

Hellal, F.A., Abdelhameid, M., Doaa, M., Abo-Basha and Zewainy, R.M. (2012) Alleviation of the adverse effects of soil salinity stress by silicon application on faba bean (Vica faba L.). J. of Applied Sci. Res. 8(8): 4428-4433.

Hendawey, M.H. (2009) Effect of salinity on proteins in some wheat cultivars. Australian J. of Basic and Applied Sci. 3(1):80-88.

Levent, A. T., Kaya, C., Higgs, D. , Murillo-Amador, B., Ayremir, S. and Girgin, A. R. (2007) Silicon improves salinity tolerance in wheat plants. Environmental and Botany 62(1):10-16.

Liang, Y.C., Chen, Q., Liu, Q., Zhang, W. and Ding, R. (2003) Effects of silicon on salinity tolerance of two barley genotypes. Journal of Plant Physiology 160: 1157-1164.

Liang, Y., Sun, W., Zhu, Y. and Christie,P. (2006) Mechanisms of silicon-medidiated alleviaitaion of abiotic stresses in higher plants: A review Environ. Pollut:1-7.

Liang, Y., Sun, W., Zhu, Y. and Christie, P. (2007) Mechanisms of silicon-mediated alleviation of abiotic stress in higher plants. A review Environ. Pollut. 147:422-428.

Ma, J.F. (2004) Role of silicon in enhancing the resitance of plants to biotic and abiotic stresses. Soil Science and Plant Nutrition 50:11-18.

Matichenkov,V.V. and Kosobrukhov, A.A. (2004) Silicon effect on the plant resistance to salt toxicity, $13^{\text {th }}$ International Soil Conservation Organization Conference, Water for Society. Brisbane, July, 2004.

Mukkram, A.T., Rahmatullah, A., Tariq, Ashraf, M., Shamsa, K. and Maqsood, M.A. (2006) Beneficial effects of Silicon in wheat (Triticum aestivum L.) under salinity stress. Pak. J. Bot. 38(5): 1715-1722.

Egypt. J. Soil Sci. 54, No. 4 (2014) 
Page, A. L. (1982) "Methods of Soil Analysis", Part 2, $2^{\text {nd }}$ ed., ASA and SSSA, Madison, Wiscansin, USA.

Qureshi, R.H. and Barrett-Lennard, E.G. (1998) "Saline Agriculture for Irrigated Land in Pakistan: Handbook", P.146, Australian Centre for International Agricultural Research (Ed.), Canberra, Australia.

Rafiq, A., Zaheer, S.H. and Ismail, S. (1992) Role of silicon in salt tolerance of wheat (Triticum aestivum L.). Plant Sci. 85(1):43-50.

Romero-Aranda, M.R., Jurado, O. and Cuartero, J. (2006) Silicon alleviates the deleterious salt effect on tomato plant growth by improving plant water status. $J$. of Plant Physiology 163: 847-855.

Saeed, A.A., Qureshi, R., Soomro, F. M., Mibbahar , A. A. and Jakhar, G.S. (2009) Effects of silicon levels on growth and yield of wheat in silty loam soil. Pak. J. Bot. 41(3):1385-1390.

Sharma, S.K., Joshi, Y.C. and Bal, A.R. (2005) Osmotic and ionic effects in salt sensitive and resistant wheat varieties. Indian Journal of Plant Physiology 27: 153158.

Shu, L.Z. and Liu, Y.H. (2001) Effects of silicon on growth of maize seedlings under salt stress. Agro-environmental Prot. 20: 38-40.

Snedecor, G. M. and Cochran, W.G. (1982) "Statistical Methods", $7^{\text {th }}$ ed., pp. 325-330 Iowa State Univ. Press, Ames, Iowa, U.S.A.

Snyder, G.H. (2001) Methods for silicon analysis in plants, soils and fertilizers. In:"Silicon in Agriculture", L.E. Datnoff, G.H. Snyder and G.H. Korndorfer (Ed.), Elsevier Science B.V., Amsterdam, The Netherlands.

Sommer, M., Kaczorek, D., Kuzyakov Y. and Breuer, J. (2006) Silicon pools and fluxes in soils and landscapes -a review. J. of Plant Nutrition and Soil Sci.169: 310-329.

Tahir, M.A., Rahmatullah, T.A., Ashraf, M., Kanwal, S. and Muhammad, A. (2006) Beneficial effects of silicon in wheat under salinity stress-pot culture. Pakistan Journal of Botany 38: 1715-1722.

Wagenet, R.J., Rodriguez, R.R., Campbell, W.F. and Turner, D.L. (1983) Fertilizer and salty water effects on Phaseolus. Agron. J. 75: 161-166.

Zhu, J. K. (2003) Regulation of ion homeostasis under salt stress. Current Opinion Plant Biology 6: 441-445.

Zhu Z., Wei, G., Li, J., Qian, Q. and Yu, J. (2004) Silicon alleviates salt stress and increases antioxidant enzymes activity in leaves of salt-stressed cucumber (Cucumis sativus L.). Plant Science 167: 527-533. 


$$
\text { وحدة المحاصيل - قهم الإنتاج النباتي - مركز بحوث الصحر اءء - القاهرة - }
$$

تم إجراء تجربتين حقليتين بمحطة مركز بحوث الصحر اء براس سدر بمحافظة

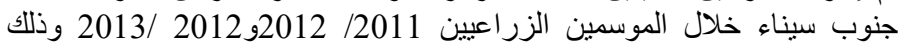

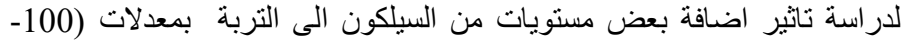

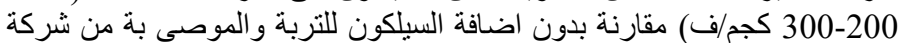

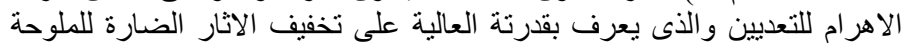

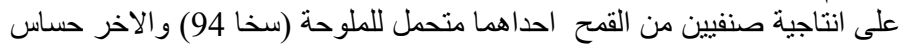

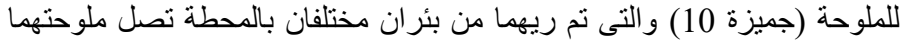

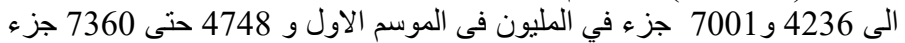
في المليون فى الموسم الثانى وقد أوضحت النتائج المتحصل عليها الأتي :-

1. بزيادة مستويات ملوحة ماء الري تقل صفات المحصول ومكوناته لكلا

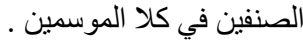

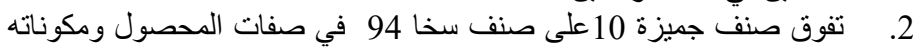
في كلا الموسمين وذللك لزيادة ارتفاع النبات بة ووزئ في في المئ المائة حبة وطول السنبلة على العكس فقد تفوق الصنف سخا 94 فى محصول البرونين النين وذلتك في كلا

زيادة محصول القمح ومكوناتة معنويا بزيادة اضافة السيلكون الى التربة

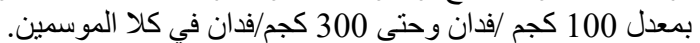

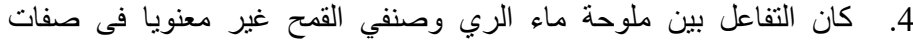

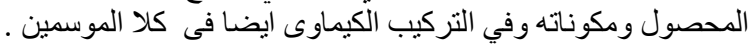

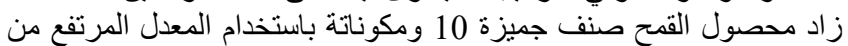

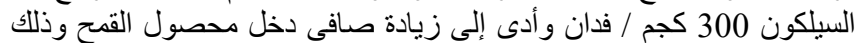
تحت الظروف الملحية فى كلا الموسميين.

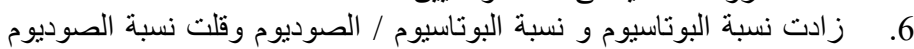

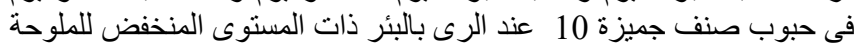

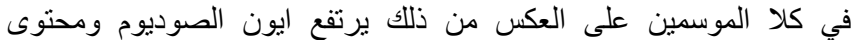
البرونين عند الرى بالتركيز المرتفع للاملاح فى صنف سنف سخا 94 وذللك فى كلا

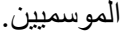

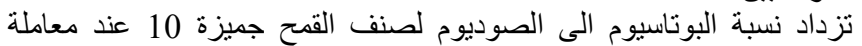

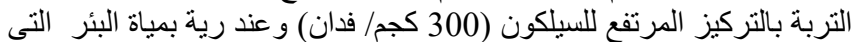

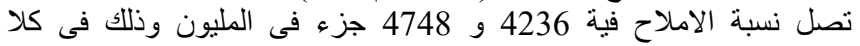

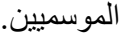

ينصح في الاراضى المتأثرة بالأملاح كما في منطقة راس سدر بمحافظة

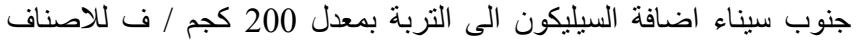
المتحملة للملوحة (سخا 94) وبمعدل 300 كجم /ف لف للاصناف الحسافة الحساسة

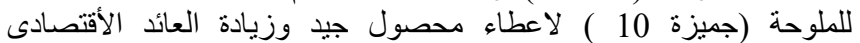
للمزار عين بالإضافة إلى تقليل التلوث من الاستخدام الزائد للأسمدة الكيماوية الألئ 